\title{
New approaches to control cucumber infestation with insects and mites with emphasis on the production and horticulture characteristics under greenhouse conditions.
}

\author{
M. F.A. Hegab ${ }^{1}$, Fahima H. Ayoub ${ }^{2}$, Badran A.B ${ }^{1}$, and Mona I. Ammar ${ }^{1}$ \\ ${ }^{1}$ Plant Protection Research Institute, Giza. Egypt. \\ ${ }^{2}$ HorticultureResearchInstitute, Giza. Egypt.
}

\begin{abstract}
The effect of different programs (foliar spray of some aromatic oils, extracts and intercropping plants with cucumber) against two insect pests, the whitefly (Bemisiatabaci (Genm)) egg and nymphal stages, thrips (Thripstabaci) and the spider mite (TetranychusurticaeKoch) eggs andmovable stages were studied. Also the cucumber horticultural characteristics, yield under the greenhouse and the tested programs conditions were evaluated. Experiments were carried out in a clay soil at Kaha Research Farm, Kalubia, Egypt, during two successive seasons of 2014and 2015.

The obtained results indicated a positive effect of all the investigated treatments in reducing infestation of the studied insect and mite pests then the control and it may be dividing them into groups between them to show significant differences during the first and second experimental seasons

Concerning the effect of the tested treatments on horticultural characteristics of cucumber plant, Data showed that T5 (basil oil spray) and T3 (citronella oil spray) followed with T6 (geranium oil) and T7(camphor oil) led to increase the cucumber growth, physical fruit characteristics, chemical leave contents, early and total yield compared with other treatments during the two studied seasons
\end{abstract}

Key wards: cucumber, whitefly, thrips, spider mite, aromatic oils, extracts and intercropping, horticultural characteristics, number of fruit and total yield

\section{Introduction}

Cucumber (Cucumissativus L.) is one of the most important vegetable crops grown in Egypt under plastic greenhouses. Cucumber plants are subjected to infestation with several pests such as insects and mites which may decrease yield by impeding plant growth, retarding flowering, sucking juice, destroying leaf area and transmit viral diseases.

In recent years the use of synthetic insecticides in crop protection programmes around the world has resulted in environmental hazards, pest resurgences, pest resistance to pesticides and lethal effect to non target organisms in the agro-ecosystems in addition to direct toxicity to users Therefore, it was necessary to search for safe alternative materials for pest control, which can minimize the use of synthetic pesticides. Botanical pesticides may be as one of important alternatives to reduce synthetic pesticides usage. They possess an array of properties including toxicity to the pest, repellency, antifeedants, insect growth regulatory activities against pests of agricultural importance (Prakashet al., 1990).

Commercially available synthetic acaricides are usually expensive and may be imported for use by farmers. They also tend to have detrimental effects on the environment and can be hazardous to humans. These negative effects have resulted in an increasing interest for natural plant- based pesticides which are assumed to be safer than the synthetic pesticides (Yanaret al., 2011)
There are several advantages to use botanical insecticides rather than synthetic (conventional) insecticides (Rebek and Sadof, 2003)

Crop pollution refers to the crop phytotoxicity resulted from pesticide applications. It affects crop growth and reduces its yield and quality. Pesticide residues have been detected in grains, vegetables, fruits, tea and medicinal herbs (Gafar et al., 2010).

Metwally et al (2008) revealed that intercropping cucumber plants with the aromatic plants, sweet basil, peppermint or spearmint led to lower spider mite infestation and produced the highest fruits yield under greenhouse and field conditions

Available growth resources, such as light, water and nutrients are more completely absorbed and converted to crop biomass by the intercropas a result of differences in competitive ability for growth factors between intercrop components. The more efficient utilization of growth resources leads to yield advantages and increased stability compared to sole cropping

Garlic produce sallicin, which has been shown to have antifungal, antibiotic and antiviral properties, and may be toxic or repellent to certain insects. It is possible that in high concentrations, the antibiotic effects of garlic become lethal to insect larvae. Garlic was somewhat slower to cause $50 \%$ mortality but it had the second highest eventual lethality. By making them not to eat their food, but it may also have had contact-toxic effects, Kalia (2015).

Natural plant extracts may play an increasingly prominent roleas alternatives to synthetic pesticides minimizing health hazards, environmental pollution 
and negative effects on non-target organisms (Sharma et al., 2006)

Capsaicin is a material extracted from chili pepper (Capsium annum L.), and used as a botanical insecticide (Xuet al., 2005) It can be used on ornamentals outdoors and indoors for control of aphids, spider mite, thrips, whitefly, and other pests. In usual use, capsaicin-containing products are primarily used to repel insects rather than to kill existing infestations. However, neither insecticidal effect nor the range of an effective concentration to a harmful insect of capsaicin is clear

The present work aimed to evaluate the biological aspects of two plant extracts, intercropping aromatic plant and five aromatic plant oils on some cucumber insect and mite pests and cucumber horticultural characteristics under greenhouse condition

\section{Material and Methods}

The present investigation was carried out in clay soil at Kaha Research Station, Kalubia Governorate during two successive spring seasons, 2014 and 2015 to study the effect of foliar spray of some aromatic oils, extracts and intercropping plants with cucumber on some horticultural characteristics of cucumber plant and its productivity and reducing infestation of the important insect and mite pestsoncucumber vegetable. Cucumber seeds c.v. Sunrise were sown in seedling trays under plastic house conditions in the nursery on $22^{\text {nd }}$ of February and seedlings were transplanted on $26^{\text {th }}$ of March in both seasons.

\section{Plant extracts:-}

Fresh mature leaves of Plectranthusamboinicus, $L$ (a wild plant with fatty leaves, grown in sub tropical and moderately regions, it was cultivated in Kaha experimental farm) were picked, washed and grind using electric mixture, the aqueous extract filtered by clean muslin for obtain leaf juice. The same technique was followed with the hot pepper fruits Both the obtained extracts were diluted down to $0.3 \%$ using fresh water and freshly applied.

\section{The experiment included 10 treatments:}

T1- Intercropping cucumber plants with (Plectranthusamboinicus(Lour.)Spreng)(one plant of P.amboinicusbetween two cucumber plants)

T2- Foliar spray with aqueous extract of P.amboinicus $(30 \mathrm{ml} / 1 \mathrm{~L}$. of water)

T3- Foliar spray with Citronella oil (Cymbopogonnardus, L) (3ml. oil+2ml. emulsifier $+1 \mathrm{~L}$. of water)

T4- Intercropping cucumber plants with Plectranthusamboinicus and foliar spray with aqueous extract of P.amboinicus(30ml/1L. of water)

T5- Foliar spray with basil oil(Ocimumbasilicum, L) (3ml. oil+2ml.emulsifier $+1 \mathrm{~L}$. of water)

T6- Foliar spray with Geranium oil (Pelargonium graveolens. L) $(3 \mathrm{ml}$. oil $+2 \mathrm{ml}$. emulsifier $+1 \mathrm{~L}$. of water
T7- Foliar spray with camphor oil (Cinnamomumcamphora, L) (3ml. oil+2 $\mathrm{ml}$. emulsifier +1L. of water)

T8- Foliar spray with garlic oil (Allium sativum.L) ( $3 \mathrm{ml}$. oil $+2 \mathrm{ml}$. emulsifier $+1 \mathrm{~L}$. of water)

T9- Foliar spray with aqueous extract of chili pepper fruit (Capsium annum, $L)(3 \mathrm{ml}$. + one litter of water $+2 \mathrm{ml}$. emulsifier)

T10- Control with foliar spray in the rate of 1L.of water $+2 \mathrm{ml}$. emulsifier only.

All the tested oils were obtained from Experimental Farm Laboratory of Medicinal and Aromatic Plants, El-KanaterElkhayria, HRI, ARC and Elgomhoria Co.

\section{Data recorded:-}

\section{I- Insects and mite infestation:}

Insecticidal sprays with the recommended chemicals were applied on seedlings at 7 days interval (one week after) germination until transplanting. The whole area of the greenhouse was divided into 10treatments. Each treatment was represented by three replicates $(35$ cucumber plants /replicate). All treatments were arranged in a randomized complete block design. All the normal agricultural practices for cucumber cultivation were followed except any other pesticidal using. Under greenhouse conditions, pesticidal control which the tested treatments were applied at 10days interval started after 10days from transplanting date until the flowering stage (5sprays) were set. Before every spray ten leaves were randomly taken /replicate from every treatment and put into paper bag then tightly closed and transferred to the laboratory for inspecting and counting the following by using stereomicroscope:

1- Number of the alive thrips individuals/ leaf.

2- Numbers of the White fly alive nymphs and eggs /leaf.

3- Number of the movable stages of the spider mite T. urticae /leaf.

Foliar sprays were applied with a knapsack sprayer equipped with one nozzle delivering 120L./feddan.

I1- Horticultural characteristics: The following data were recorded:

\section{1- Vegetative growth characteristics:}

Data were recorded on plant height $(\mathrm{cm})$, number of leaves per plant and leaf area $\left(\mathrm{cm}^{2}\right)$ for the above six leaves from the top of plant, then measured by using LI3000 Portable Area Meter (PAM) No. 5, produced by Li-cor Pennsylvania, fresh and dry weight (g/plant) which determined by pulled up of three plants randomly from each replicate and dried at $70^{\circ} \mathrm{C}$.

\section{2- Leaves chemical composition:}

Data were recorded on leaves chlorophyll content that determined by Minlolta chlorophyll meter SPAD $-50 \%$ 
The total phenol were estimated following the procedure of Swains and Hillis (1959), total sugars and reducing sugars were analyzed according to Duhois et al., (1956) and Anonymous (1990) respectively.

\section{3- Fruit quality:}

Data concerning fruit characteristics were collected when the marked flowers reached the marketing fruit size. Data were recorded on average fruit length $(\mathrm{cm})$, diameter $(\mathrm{cm})$ and weight $(\mathrm{g})$.

\section{4- Early and total yield:}

Data were recorded on early and total yield as number and weight of picked fruits. Early yield was recorded for fruits picked at the first four harvests, while total yield was recorded for all fruits harvest.

\section{III- Statistical analysis}

The obtained data were subjected to the analysis of variance procedure and means comparison using the L.S.D. method at $5 \%$ level of significance according to Gomez and Gomez (1984).

\section{Results and Discussion}

\section{Effect of the tested treatment on:}

\section{I - Insects and mite infestation}

Data in tables (1 and 2) demonstrate the action of the tested aromatic oils, plant extract and Plectranthusamboinicus plant intercropping by 5 spray applications, revealed a great variations in the effectiveness against the infestation of thrips individuals, white fly eggs, nymphal stages and the spider mite eggs and movable stages on cucumber plants under greenhouse conditions during the two successive seasons 2014 and 2015. Obtained results indicated the following:

\section{1- On thrips infestation:-}

Highly significant differences appeared between the tested treatments (L.S.D.0.60 at 0.05) during 2014, the intercropping Plectranthusamboinicus(T1) and P.amboinicusextract (T2) varied significantly than the other treatments. According to the effect on the mean number of infested plants which represented by number of thrips individuals/cucumber leaf, it may arranging the tested treatments descendingly based on the L.S.D value to the following groups and there were no significant differences between the insecticidal activities of the treatments of each group:

1) T6 and T5 recording 0.63 and 0.87 insect /leaf

2) $\mathrm{T} 7$ and $\mathrm{T} 9$ recorded 1.5 and 1.93 insect /leaf.

3) T8 and T3 recording 2.03 and 2.6 insect /leaf.

4) T4 recording 8.23 insects /leaf.

5) T2 and T1 recording 11.45 and 12.08 insect /leaf.

From the above mentioned results T6 (geranium oil spray) and T5 (basil oil spray) had the strongest effect to reduce the infestation of thrips insect pest lasting to the lowest population level 0.63 and 0.87 insects /leaf, in contrast T2 (P.amboinicusextract spray) and T1 (intercropping P.amboinicus) had the lowest effect on thrips population causing the highest infestation on cucumber plants 11.45 and 12.08 insects /leaf.

Table 1. Effect of some aromatic oils, plant extract and intercropping on thrips, white fly and spider mite infestation on cucumber plants under greenhouse condition (first season spring 2014)

\begin{tabular}{|c|c|c|c|c|c|c|}
\hline \multirow[b]{3}{*}{$\begin{array}{l}\text { T. } \\
\text { No. }\end{array}$} & \multirow[b]{3}{*}{ Tested treatments } & \multicolumn{5}{|c|}{ First season 2014} \\
\hline & & \multicolumn{5}{|c|}{ Mean number /leaf of: } \\
\hline & & Thrips & $\begin{array}{c}\text { White } \\
\text { fly } \\
\text { eggs }\end{array}$ & $\begin{array}{l}\text { White fly } \\
\text { nymphs }\end{array}$ & $\begin{array}{l}\text { Spider mite } \\
\text { eggs }\end{array}$ & $\begin{array}{l}\text { Spider mite } \\
\text { movable stages }\end{array}$ \\
\hline 1 & Intercropping & & & & & \\
\hline & withPlectranthusamboinicus & $12.08 \mathrm{~b}$ & $28.43 b$ & $17.08 \mathrm{~b}$ & $34.37 \mathrm{~b}$ & $17.00 \mathrm{~b}$ \\
\hline 2 & Plectranthusamboinicus extract & $11.45 \mathrm{c}$ & $17.50 \mathrm{c}$ & $12.13 \mathrm{c}$ & $13.75 d$ & $9.27 \mathrm{~d}$ \\
\hline 3 & Citronella oil & $2.60 \mathrm{e}$ & $1.47 \mathrm{f}$ & $2.42 \mathrm{gh}$ & $1.67 f$ & $0.35 \mathrm{i}$ \\
\hline 4 & $\begin{array}{l}\text { Intercropping } \\
\text { andPlectranthusamboinicus }\end{array}$ & & & & & \\
\hline & extract & $8.23 \mathrm{~d}$ & $11.13 \mathrm{~d}$ & $9.50 \mathrm{~d}$ & $11.83 \mathrm{~d}$ & $7.83 \mathrm{e}$ \\
\hline 5 & Basil oil & $0.87 \mathrm{~g}$ & $1.20 \mathrm{f}$ & $1.67 \mathrm{~h}$ & $2.77 f$ & $1.80 \mathrm{~h}$ \\
\hline 6 & Geranium oil & $0.63 \mathrm{~g}$ & $4.00 \mathrm{e}$ & $3.27 \mathrm{f}$ & $3.83 \mathrm{f}$ & $2.83 \mathrm{~g}$ \\
\hline 7 & Camphor oil & $1.50 \mathrm{f}$ & $1.33 \mathrm{f}$ & $2.60 \mathrm{fg}$ & $1.87 \mathrm{f}$ & $2.13 \mathrm{~h}$ \\
\hline 8 & Garlic oil & $2.03 \mathrm{ef}$ & $3.00 \mathrm{ef}$ & $9.30 \mathrm{~d}$ & $8.67 \mathrm{e}$ & $3.80 \mathrm{f}$ \\
\hline 9 & Hot pepper extract & $1.93 \mathrm{f}$ & $4.10 \mathrm{e}$ & $8.37 \mathrm{e}$ & $22.67 \mathrm{c}$ & $12.03 \mathrm{c}$ \\
\hline 10 & Control & $32.25 \mathrm{a}$ & $30.33 a$ & $42.00 \mathrm{a}$ & $105.67 \mathrm{a}$ & $53.57 \mathrm{a}$ \\
\hline & L.S.D 5\% & 0.60 & 1.75 & 0.76 & 2.40 & 0.45 \\
\hline
\end{tabular}


Table 2. Effect of some aromatic oils, plant extract and intercropping on thrips, white fly and spider mite infestation on cucumber plants under greenhouse condition (second season spring 2015)

\begin{tabular}{|c|c|c|c|c|c|c|}
\hline \multirow{3}{*}{$\begin{array}{c}\text { T. } \\
\text { No. }\end{array}$} & \multirow[b]{3}{*}{ Tested treatments } & \multicolumn{5}{|c|}{ Second season 2015} \\
\hline & & \multicolumn{5}{|c|}{ Mean number /leaf of: } \\
\hline & & Thrips & $\begin{array}{l}\text { White } \\
\text { fly eggs }\end{array}$ & $\begin{array}{l}\text { White fly } \\
\text { nymphs }\end{array}$ & $\begin{array}{l}\text { Spider mite } \\
\text { eggs }\end{array}$ & $\begin{array}{c}\text { Spider mite } \\
\text { movable stages }\end{array}$ \\
\hline \multirow[t]{2}{*}{1} & Intercropping & & & & & \\
\hline & withPlectranthusamboinicus & $11.8 b$ & $27.8 b$ & $15.80 \mathrm{~b}$ & $31.3 b$ & $15.9 \mathrm{~b}$ \\
\hline 2 & Plectranthusamboinicus extract & $11.6 b$ & $14.2 \mathrm{c}$ & $11.70 \mathrm{c}$ & $12.7 \mathrm{~d}$ & $8.8 \mathrm{~d}$ \\
\hline 3 & Citronella oil & $2.33 b$ & $1.2 \mathrm{~g}$ & $2.30 \mathrm{fg}$ & $1.5 \mathrm{i}$ & $0.3 \mathrm{j}$ \\
\hline \multirow[t]{2}{*}{4} & Intercropping & & & & & \\
\hline & $\begin{array}{l}\text { andPlectranthusamboinicus } \\
\text { extract }\end{array}$ & $8.20 \mathrm{c}$ & $10.2 \mathrm{~d}$ & $8.70 \mathrm{~d}$ & $11.0 \mathrm{e}$ & $7.1 \mathrm{e}$ \\
\hline 5 & Basil oil & $0.70 \mathrm{~g}$ & $1.0 \mathrm{~g}$ & $1.33 \mathrm{~h}$ & $2.8 \mathrm{~h}$ & $1.2 \mathrm{i}$ \\
\hline 6 & Geranium oil & $0.53 \mathrm{~g}$ & $3.0 \mathrm{e}$ & $2.50 \mathrm{f}$ & $3.7 \mathrm{~g}$ & $2.4 \mathrm{~g}$ \\
\hline 7 & Camphor oil & $1.33 f$ & $1.2 \mathrm{~g}$ & $2.10 \mathrm{~g}$ & $1.7 \mathrm{i}$ & $1.8 \mathrm{~h}$ \\
\hline 8 & Garlic oil & $1.80 \mathrm{e}$ & $2.0 \mathrm{f}$ & $9.00 \mathrm{~d}$ & $8.4 \mathrm{f}$ & $3.4 \mathrm{f}$ \\
\hline 9 & Hot pepper extract & $1.80 \mathrm{e}$ & $3.1 \mathrm{e}$ & $8.20 \mathrm{e}$ & $21.2 \mathrm{c}$ & $11.7 \mathrm{c}$ \\
\hline \multirow[t]{2}{*}{10} & Control & $31.22 \mathrm{a}$ & $31.7 \mathrm{a}$ & $40.90 \mathrm{a}$ & $103.9 \mathrm{a}$ & $53.3 \mathrm{a}$ \\
\hline & L.S.D 5\% & 0.39 & 0.38 & 0.34 & 0.57 & 0.38 \\
\hline
\end{tabular}

The remaining tested treatments could be classified to have an intermediate effect in reducing the pest infestation comparing with the control (32.25 insects /leaf) those including treatments No. $3,4,7,8$ and 9 which were citronella oil sprays, intercropping and the spray of Plectranthusamboinicus extract, camphor oil, garlic oil and hot pepper extract sprays, respectively.

During the second season 2015, rates of infestation (Table 2) affected by the tested treatments and had a similar trend with that occurred in the first season.

\section{2- On white fly}

Results in Tables (1and 2) revealed the effect of the tested treatments on the mean number of white fly egg and nymphal stages /leaf of cucumber. In the first season the effectiveness of the examined treatments varied significantly according the base of the L.S.D.1.75 for the eggs at the level 5\% and it could be categorized dscendingly to the four variable groups as follows:

1) $\mathrm{T} 5, \mathrm{~T} 7$ and $\mathrm{T} 3$ recording 1.2, 1.33 and 1.47, eggs/leaf.

2) T8, T6 and T9 recording 3.0, 4.0 and 4.1 eggs/leaf.

3) T4 recording11.13 eggs/leaf.

4) T2 and T1 recording 17.5 and 28.43 eggs/leaf.

These results indicated again that $\mathrm{T} 2$ (extract spray) and T1 (intercropping) had the lowest effect on the eggs of white fly casing the highest infestation and the largest number of eggs/leaf. on the other hand the strongest effect were obtained by applications of T5, T7 and T3 which were basil oil, camphor oil citronella oil sprays, respectively. The remaining treatments had intermediate effect in this respect.

In respect to white fly nymphs as indicated in the same Table (1) it is possible to divide the tested treatments into six groups varied significantly based on the (L.S.D. 0.76) also, these groups still had the same trend as in the case of thrips insects and eggs of the white fly population revealing that treatments No. 5,3 and 7 were the most effective in reducing the population and reducing the infestation with thrips and white fly, and treatments No. 1 and 2 were the most weakest. Results in (Table 2) proved that the effect of investigated treatments had the same trend as mentioned above.

\section{3-On the spider mite}

Data in the Tables (1 and 2) clearly indicate the efficiency of the tested treatments against the population of the spider mite (Tetranychusurticae) eggs and movable stages on cucumber plants under greenhouse conditions during the spring plantations of 2014 and 2015 seasons. Based on the L.S.D. value at the $5 \%$ level, the population of the pest eggs varied significantly according to the used treatment during 2014 season (L.S.D.= 2.4) compared to the control. Results may be arranged decendingly according to the infestation affected by the tested treatments into 5 groups as follows:

1) T3, T7, T5 and T6 recording 1.67, 1.87, 2.77 and 3.83, eggs/leaf respectively.

2) $\quad \mathrm{T} 8(8.67$ eggs/leaf $)$.

3) $\mathrm{T} 4$ and $\mathrm{T} 2$ recording 11.83 and 13.75 eggs/leaf.

4) $\mathrm{T} 9(22.67$ eggs/leaf).

5) T1 (34.37 eggs/leaf).

No significant differences were obtained between the treatments inside the groups, but between the above mentioned groups and the results indicated that T1 (intercropping) and T9 (hot pepper extract) had the lowest effect on the spider eggs causing the highest infestation 34.37 eggs /leaf and 22.67 eggs/leaf while T9 and T7 gave the strongest effect (1.67and 1.87 eggs/leaf). 
In the second season 2015 the same trend of effect was observed but the significant differences were wider between groups and again indicated the strongest effect of $\mathrm{T} 3$ (citronella oil) and $\mathrm{T} 7$ (camphor oil) causing the lowest infestation 1.5 and 1.7 eggs/leaf and T1 and T9 were still having the lowest effect.

On the other hand the effect of the examined treatments on the spider mite movable stages in the two tables 1 and 2 results proved clearly that $\mathrm{T} 1$ and T9 had the most weakest effect on the population of spider mite individuals causing the largest infestation 17.0 and 12.03 during 2014 and 15.9, 11.7 individuals /leaf in 2015 season.

Also T3 (citronella oil) and T5(basil oil) proved to be the strongest treatments in reducing the infestation with the spider mite movable stages during the two tested season lasting to $0.35,1.8$ and $0.3,1.2$ individuals of movable stages/cucumber leaf during 2014 and 2015 season, respectively.

In tables 1 and 2, the statistical analysis calculated the L.S.D. values indicated the significant differential among the activities of the tested applications by the statistical analysis groups. Also there were no significant differences between the insecticidal activities of the treatments of each group and the means signed with the same letter are not significantly different. Many reported were published during the last decades dealing with plant - derived essential product evaluation for both efficacy against insect and mite pests and plant safety. The above motioned results are in agreement with the findings of Raymond et al., 2009 who found that garlic oil was the most effective against the two spotted spider mite causing $90 \%$ mortality and citronella oil providing $80 \%$ mortality. Also the results of Mohamed and Mahasen, 2008 revealed that the oily extract of Tagetsminita L. showed good level of efficiency against cotton aphids, whitefly and thrips. Mangoud \& Halawa ., 2007 revealed that the garlic water extract came in the first then the black seeds extract and in the end came the Pink flowers extract for reducing the number of the two spotted spider mite. Chili pepper contains capsaicin which creates the hot, spicy effect. Capsaicin at 10 parts per million causes a persistent burning sensation. Capsaicin works by opening doors in the cell membranes that enable calcium ions to flood into the cell. Extremely high concentrations of capsaicin are toxic. By boiling the chilies, isolated and concentrated the capsaicin and other chemicals. Because greater wax moth larvae are small and soft-bodied insects, sufficiently high concentrations might contain enough capsaicin to destroy cells and kill them. Another possibility is the acidity of hot peppers: the soft skin of a wax moth might be damaged by the pepper's chemicals. (Xu et al., 2005)

\section{II- Horticultural characteristics}

\section{A- Vegetative growth:}

Data in Table (3) demonstrate the action of the tested aromatic oils; plant extract and intercropping which showed that there were significant differences between the tested treatments on vegetative growth characteristics during the two studied seasons. Data indicated that T5 (basil oil spray) and T3 (citronella oil spray) followed with T6 (geranium oil) and T7(camphor oil) led to increase the cucumber growth in terms of plant height, number of leaves, leaf area, fresh and dry weight per plant in both seasons compared with the other treatments. On the other hand, T2 (Plectranthusamboinicus extract spray) and T1 (intercropping P.amboinicus) had the lowest effect on cucumber vegetative growth. These results may be due to the effect of treatments on insect and mites infestation

\section{B- Fruit characteristics}

The obtained results in Table (4) indicated that T5 (basil oil spray) and T3 (citronella oil spray) followed with T6 (geranium oil) and T7 (camphor oil) have positive effect in cucumber fruit characteristics. Data showed that T5 and T3 led to significant increase the average fruit length, and average fruit weight during the two studied seasons compared with the other treatments. On the other hand the tested treatments had no significant effect on fruit diameter. These results could be attributed to the increase of vegetative growth characteristics with T5 and $\mathrm{T} 3$.

\section{c- Leaves chemical composition}

Data in Table (5) indicated positive effect of the tested treatments on leaves chemical composition (chlorophyll, proline, phenol, total sugar, and reducing sugar) of cucumber plants grown under greenhouse during the two studied seasons. Data cleared that T5 and T3 followed with T6 and T7 led to increase the total chlorophyll and total sugar and decrease the proline, phenol and reducing sugar. Moreover, it's noticed that with increasing in the mean number of infestation, corresponding decrease in the total soluble sugars and increase in proline, phenol and reducing sugar are shown in treatments T1. T2 and control most herbivorous insects and mites use carbohydrates as feeding stimulant, nutrient needed to synthesize body tissue and energy source (Schoonhoven et al., 1998). Derridj et al. (1989) reported role of sugars in promoting oviposition in some species.

A strong and persistent flow of host assimilates is created by the continual removal of metabolites and breakdown of insoluble reserves by insects. 
Table 3. Effect of some aromatic oils, plant extract and intercropping on vegetative growth of cucumber plants

\begin{tabular}{|c|c|c|c|c|c|c|}
\hline & & $\begin{array}{l}\text { Plant height } \\
(\mathrm{cm})\end{array}$ & $\begin{array}{l}\text { No. of } \\
\text { leaves } \\
\text { /plant }\end{array}$ & $\begin{array}{c}\text { Leaf } \\
\text { Area }\left(\mathrm{cm}^{2}\right)\end{array}$ & $\begin{array}{c}\text { Leaves fresh } \\
\text { weight }(\mathrm{g})\end{array}$ & $\begin{array}{c}\text { Leaves dry } \\
\text { weight (g) }\end{array}$ \\
\hline $\mathrm{T}$ & Tested treatments & \multicolumn{5}{|c|}{ First season 2014} \\
\hline \multirow[t]{2}{*}{1} & Intercropping with & & & & & \\
\hline & Plectranthusamboinicus & $242.00 \mathrm{c}$ & $42.33 d$ & $73.08 \mathrm{~h}$ & $341.95 \mathrm{~g}$ & $58.10 \mathrm{f}$ \\
\hline 2 & $\begin{array}{l}\text { Plectranthusamboinicus } \\
\text { extract }\end{array}$ & $252.67 d$ & $44.33 \mathrm{~d}$ & $76.10 \mathrm{~g}$ & $362.87 f$ & $67.93 \mathrm{e}$ \\
\hline 3 & Citronella oil & $270.33 a$ & $56.33 \mathrm{a}$ & $83.03 \mathrm{~b}$ & $461.85 b$ & $74.49 b$ \\
\hline 4 & $\begin{array}{l}\text { Intercropping and } \\
\text { Plectranthusamboinicus } \\
\text { extract }\end{array}$ & $256.33 d$ & $48.33 c$ & $77.17 f$ & $373.69 \mathrm{e}$ & $67.98 \mathrm{e}$ \\
\hline 5 & Basil oil & $271.00 \mathrm{a}$ & $57.67 \mathrm{a}$ & $85.97 \mathrm{a}$ & $482.67 \mathrm{a}$ & $87.75 \mathrm{a}$ \\
\hline 6 & Geranium oil & $259.33 b$ & $52.33 b$ & $81.26 \mathrm{~cd}$ & $453.28 b$ & $72.13 \mathrm{~cd}$ \\
\hline 7 & Camphor oil & $259.67 b$ & $53.00 \mathrm{~b}$ & $81.60 \mathrm{c}$ & $456.46 b$ & $72.78 \mathrm{c}$ \\
\hline 8 & Garlic oil & $259.00 \mathrm{~b}$ & $49.00 \mathrm{c}$ & $80.89 d$ & $428.40 \mathrm{c}$ & $71.54 \mathrm{~cd}$ \\
\hline 9 & Hot pepper extract & $258.33 b$ & $48.67 \mathrm{c}$ & $79.33 \mathrm{e}$ & $392.05 d$ & $70.68 \mathrm{~d}$ \\
\hline 10 & Control & $212.33 d$ & $32.67 \mathrm{e}$ & $69.83 \mathrm{i}$ & $294.87 \mathrm{~h}$ & $52.87 \mathrm{~g}$ \\
\hline \multicolumn{2}{|c|}{ L.S.D 5\% } & 6.94 & 2.88 & 0.39 & 9.18 & 1.75 \\
\hline & & \multicolumn{5}{|c|}{ Second season 2015} \\
\hline \multirow[t]{2}{*}{1} & Intercropping with & & & & & \\
\hline & Plectranthusamboinicus & $246.00 \mathrm{~d}$ & $43.67 \mathrm{e}$ & $74.11 \mathrm{~g}$ & $345.65 f$ & $58.71 \mathrm{e}$ \\
\hline 2 & Plectranthusamboinicus & $25000 \mathrm{c}$ & $4800 \mathrm{~d}$ & $7768 f$ & 36776 & $6825 d$ \\
\hline 3 & Citronella oil & $273.33 \mathrm{ab}$ & $62.00 \mathrm{a}$ & $91.04 \mathrm{~b}$ & $467.10 \mathrm{ab}$ & $75.26 \mathrm{~b}$ \\
\hline \multirow[t]{2}{*}{4} & Intercropping and & & & & & \\
\hline & $\begin{array}{l}\text { Plectranthusamboinicus } \\
\text { extract }\end{array}$ & $259.67 \mathrm{c}$ & $49.00 \mathrm{~cd}$ & $77.90 \mathrm{f}$ & $376.46 \mathrm{de}$ & $71.23 \mathrm{~cd}$ \\
\hline 5 & Basil oil & $275.67 \mathrm{a}$ & $64.33 \mathrm{a}$ & $96.45 \mathrm{a}$ & $487.32 \mathrm{a}$ & $88.59 \mathrm{a}$ \\
\hline 6 & Geranium oil & $266.67 \mathrm{bc}$ & $51.67 \mathrm{bc}$ & $80.88 \mathrm{~d}$ & $457.50 \mathrm{bc}$ & $72.80 \mathrm{bc}$ \\
\hline 7 & Camphor oil & $267.00 b c$ & $54.00 \mathrm{~b}$ & $81.68 \mathrm{c}$ & $461.16 b$ & $74.30 \mathrm{bc}$ \\
\hline 8 & Garlic oil & $263.67 \mathrm{c}$ & $51.00 \mathrm{c}$ & $78.71 \mathrm{e}$ & $437.33 c$ & $72.35 \mathrm{bc}$ \\
\hline 9 & Hot pepper extract & $261.33 c$ & $50.00 \mathrm{~cd}$ & $78.48 \mathrm{e}$ & $393.19 d$ & $72.15 b c$ \\
\hline 10 & Control & $219.33 \mathrm{e}$ & $34.00 \mathrm{f}$ & $64.56 \mathrm{~h}$ & $303.72 \mathrm{~g}$ & $55.04 \mathrm{f}$ \\
\hline L.S.D & $5 \%$ & 8.06 & 2.73 & 0.23 & 20.28 & 3.49 \\
\hline
\end{tabular}

Table 4. Effect of some aromatic oils, plant extract and intercropping on fruit characteristics

\begin{tabular}{|c|c|c|c|c|c|c|c|}
\hline \multirow[b]{2}{*}{$\mathbf{T}$} & \multirow[b]{2}{*}{ Tested treatments } & \multicolumn{3}{|c|}{ First season 2014} & \multicolumn{3}{|c|}{ Second season 2015} \\
\hline & & $\begin{array}{l}\text { Fruit } \\
\text { length } \\
(\mathrm{cm})\end{array}$ & $\begin{array}{l}\text { Fruit } \\
\text { diameter } \\
(\mathrm{cm}) \\
\end{array}$ & $\begin{array}{l}\text { Fruit } \\
\text { weight } \\
(\mathrm{g})\end{array}$ & $\begin{array}{l}\text { Fruit } \\
\text { length } \\
(\mathrm{cm})\end{array}$ & $\begin{array}{l}\text { Fruit } \\
\text { diameter } \\
(\mathrm{cm}) \\
\end{array}$ & $\begin{array}{l}\text { Fruit } \\
\text { weight } \\
(\mathrm{g}) \\
\end{array}$ \\
\hline 1 & $\begin{array}{l}\text { Intercropping with } \\
\text { Plectranthusamboinicus }\end{array}$ & $16.00 \mathrm{f}$ & 3.20 & $110.65 \mathrm{ef}$ & $16.83 \mathrm{~cd}$ & 3.23 & $111.65 \mathrm{ef}$ \\
\hline 2 & $\begin{array}{l}\text { Plectranthusamboinicus } \\
\text { extract }\end{array}$ & $16.43 \mathrm{def}$ & 3.17 & $112.93 \mathrm{e}$ & $17.00 \mathrm{~cd}$ & 3.20 & 114.59def \\
\hline 3 & Citronella oil & $17.90 \mathrm{ab}$ & 3.37 & $125.79 b$ & $18.13 \mathrm{ab}$ & 3.43 & $123.54 \mathrm{bc}$ \\
\hline 4 & $\begin{array}{l}\text { Intercropping and } \\
\text { Plectranthusamboinicus } \\
\text { extract }\end{array}$ & $16.73 \mathrm{def}$ & 3.17 & $113.67 \mathrm{e}$ & $17.00 \mathrm{~cd}$ & 3.27 & $115.65 \mathrm{def}$ \\
\hline 5 & Basil oil & $18.33 \mathrm{a}$ & 3.53 & $132.87 \mathrm{a}$ & $18.50 \mathrm{a}$ & 3.57 & $133.29 \mathrm{a}$ \\
\hline 6 & Geranium oil & $17.33 \mathrm{bcd}$ & 3.37 & $119.86 \mathrm{~cd}$ & $17.67 \mathrm{abc}$ & 3.30 & $123.08 \mathrm{bc}$ \\
\hline 7 & Camphor oil & $17.67 \mathrm{abc}$ & 3.20 & $122.62 \mathrm{bc}$ & $18.00 \mathrm{ab}$ & 3.43 & $127.19 \mathrm{ab}$ \\
\hline 8 & Garlic oil & $17.00 \mathrm{cde}$ & 3.13 & $114.85 \mathrm{de}$ & $17.33 \mathrm{bc}$ & 3.27 & $117.37 \mathrm{cde}$ \\
\hline 9 & Hot pepper extract & $17.00 \mathrm{cde}$ & 3.20 & $116.04 \mathrm{de}$ & $17.07 \mathrm{~cd}$ & 3.23 & $118.60 \mathrm{~cd}$ \\
\hline 10 & Control & $16.06 \mathrm{ef}$ & 3.17 & $107.41 \mathrm{f}$ & $16.40 \mathrm{~d}$ & 3.20 & $108.74 f$ \\
\hline & S.D 5\% & 0.87 & N.S & 5.04 & 0.66 & N.S & 5.99 \\
\hline
\end{tabular}


The phloem-feeding $T$. urticaecontinually controls and/or modifies the levels of metabolic substances in the surrounding tissues. This is supported in the current work where the levels of total sugars of infested cucumber leaves were lower than those of healthy ones. This effect of mite feeding on total soluble sugar content was also reported in chrysanthemum, bean and cucumber plants (Tomczyk, 2001), soybean (Hildebrand et al., 1986)، grapevine (Sivritepe et al., 2009) and bean (Farouk and Osman, 2012). However, it has been noticed that the amount of reducing sugars showed an increase over control in T.urticae infested cucumber leaves in the current study. Such effect might be due to decreased efficiency of conversion of monosaccharide's (particularly glucose) into polysaccharides, leading to their accumulation (Tomczyk, 2001).These results also corroborate with those of Senthil et al. (2010), who reported increased total phenols in infected plants and claimed that they might play an important role in plant defence by increasing the physical and mechanical strength of the host cell wall. Proline is another important component of the defense system of plants to counter stress.

Table 5. Effect of some aromatic oils, plant extract and intercropping on leaves chemical composition

\begin{tabular}{|c|c|c|c|c|c|c|}
\hline & Tested treatments & $\begin{array}{l}\text { Proline } \mu \mathrm{g} \\
/ 100 \mathrm{mg} \mathrm{f.w}\end{array}$ & $\begin{array}{l}\text { Phenol } \\
(\mathrm{mg} / \mathrm{g} \mathrm{dw})\end{array}$ & $\begin{array}{l}\text { Total sugar } \\
\mathrm{mg} / \mathrm{g} \text { d.w }\end{array}$ & $\begin{array}{l}\text { Reducing } \\
\text { sugar } \mathrm{mg} / \mathrm{g} \text { d.w }\end{array}$ & $\begin{array}{l}\text { Clorophyll } \\
\text { SPAD }\end{array}$ \\
\hline & & \multicolumn{5}{|c|}{ First season 2014} \\
\hline 1 & $\begin{array}{l}\text { Intercropping with } \\
\text { Plectranthusamboinicus }\end{array}$ & $25.75 b$ & $0.48 b$ & $1.72 \mathrm{ef}$ & $0.99 b$ & $63.73 \mathrm{c}$ \\
\hline 2 & $\begin{array}{l}\text { Plectranthusamboinicus } \\
\text { extract }\end{array}$ & $25.67 \mathrm{~b}$ & $0.46 b c$ & $1.75 \mathrm{e}$ & $0.94 \mathrm{c}$ & $66.21 b$ \\
\hline 3 & Citronella oil & $22.37 f$ & $0.39 \mathrm{f}$ & $2.06 \mathrm{~b}$ & $0.82 \mathrm{e}$ & $77.97 \mathrm{a}$ \\
\hline 4 & $\begin{array}{l}\text { Intercropping and } \\
\text { Plectranthusamboinicus } \\
\text { extract }\end{array}$ & $25.37 \mathrm{c}$ & $0.46 b c$ & $1.77 \mathrm{e}$ & $0.93 \mathrm{c}$ & $69.20 \mathrm{~b}$ \\
\hline 5 & Basil oil & $20.33 \mathrm{~g}$ & $0.35 \mathrm{~g}$ & $2.20 \mathrm{a}$ & $0.79 \mathrm{f}$ & $82.93 a$ \\
\hline 6 & Geranium oil & $24.22 \mathrm{~d}$ & $0.42 \mathrm{de}$ & $1.88 \mathrm{~d}$ & $0.86 \mathrm{~d}$ & $70.43 b$ \\
\hline 7 & Camphor oil & $23.12 \mathrm{e}$ & $0.41 \mathrm{ef}$ & $1.95 \mathrm{c}$ & $0.85 \mathrm{~d}$ & $77.30 \mathrm{a}$ \\
\hline 8 & Garlic oil & $24.22 \mathrm{~d}$ & $0.44 \mathrm{~cd}$ & $1.87 \mathrm{~d}$ & $0.87 \mathrm{~d}$ & $70.40 \mathrm{~b}$ \\
\hline 9 & Hot pepper extract & $24.38 \mathrm{~d}$ & $0.44 \mathrm{~cd}$ & $1.79 \mathrm{e}$ & $0.92 \mathrm{c}$ & $69.67 \mathrm{~b}$ \\
\hline \multirow[t]{3}{*}{10} & Control & $29.25 \mathrm{a}$ & $0.51 \mathrm{a}$ & $1.66 \mathrm{f}$ & $1.08 \mathrm{a}$ & $56.76 \mathrm{c}$ \\
\hline & L.S.D $5 \%$ & 0.176 & 0.02 & 0.06 & 0.01 & 6.36 \\
\hline & & \multicolumn{5}{|c|}{ Second season 2015} \\
\hline 1 & $\begin{array}{l}\text { Intercropping with } \\
\text { Plectranthusamboinicus }\end{array}$ & $25.66 \mathrm{~b}$ & $0.46 b$ & $1.72 \mathrm{ab}$ & $0.98 b$ & $59.23 \mathrm{f}$ \\
\hline 2 & $\begin{array}{l}\text { Plectranthusamboinicus } \\
\text { extract }\end{array}$ & $25.37 \mathrm{c}$ & $0.46 b$ & $1.72 \mathrm{ab}$ & $0.97 \mathrm{bc}$ & $58.94 \mathrm{f}$ \\
\hline 3 & Citronella oil & $22.41 \mathrm{~h}$ & $0.34 \mathrm{e}$ & $1.94 \mathrm{a}$ & $0.80 \mathrm{f}$ & $77.59 \mathrm{ab}$ \\
\hline 4 & $\begin{array}{l}\text { Intercropping and } \\
\text { Plectranthusamboinicus } \\
\text { extract }\end{array}$ & $24.12 d$ & $0.45 b$ & $1.75 \mathrm{ab}$ & $0.94 \mathrm{~cd}$ & $61.33 \mathrm{cde}$ \\
\hline 5 & Basil oil & $21.12 \mathrm{i}$ & $0.32 \mathrm{e}$ & $2.19 \mathrm{a}$ & $0.79 \mathrm{f}$ & $81.91 \mathrm{a}$ \\
\hline 6 & Geranium oil & $23.05 \mathrm{~g}$ & $0.42 \mathrm{~cd}$ & $1.85 \mathrm{a}$ & $0.91 \mathrm{~d}$ & $66.51 \mathrm{c}$ \\
\hline 7 & Camphor oil & $23.00 \mathrm{~g}$ & $0.41 \mathrm{~d}$ & $1.89 \mathrm{a}$ & $0.85 \mathrm{e}$ & $73.51 b$ \\
\hline 8 & Garlic oil & $23.73 \mathrm{f}$ & $0.43 \mathrm{bcd}$ & $1.83 \mathrm{ab}$ & $0.92 d$ & $65.39 \mathrm{~cd}$ \\
\hline 9 & Hot pepper extract & $24.00 \mathrm{e}$ & $0.44 \mathrm{bc}$ & $1.79 \mathrm{ab}$ & $0.93 \mathrm{~d}$ & $61.40 \mathrm{cde}$ \\
\hline \multirow[t]{2}{*}{10} & Control & $27.35 \mathrm{a}$ & $0.49 \mathrm{a}$ & $1.51 \mathrm{~b}$ & $1.15 \mathrm{a}$ & $58.68 \mathrm{f}$ \\
\hline & L.S.D 5\% & 0.10 & 0.03 & 0.27 & 0.03 & 5.30 \\
\hline
\end{tabular}

\section{d- Early and total yield}

Data in Table (6) cleared that T5 (basil oil spray) and T3 (citronella oil spray) followed with T6 (geranium oil) and T7 (camphor oil) led to significantly increase number of fruits and total yield per plant during the two studied seasons. These results may be due to the effect of treatments on insects and mites infestation as shown in Tables (1, 2). 
Table 6. Effect of some aromatic oils, plant extract and intercropping on early and total yield/plant

\begin{tabular}{|c|c|c|c|c|c|}
\hline \multirow[t]{3}{*}{$\mathrm{T}$} & \multirow[b]{3}{*}{ Tested treatments } & \multicolumn{2}{|c|}{ Early yield/plant } & \multicolumn{2}{|c|}{ Total yield/plant } \\
\hline & & NO. & Weight kg & NO. & Weight kg \\
\hline & & \multicolumn{4}{|c|}{ First season 2014} \\
\hline 1 & Intercropping with Plectranthusamboinicus & $3.46 \mathrm{e}$ & $0.420 \mathrm{~g}$ & $15.74 \mathrm{bc}$ & $1.650 \mathrm{e}$ \\
\hline 2 & Plectranthusamboinicus extract & $4.05 \mathrm{~d}$ & $0.477 \mathrm{f}$ & $16.16 \mathrm{bc}$ & $1.930 \mathrm{~d}$ \\
\hline 3 & Citronella oil & $4.93 \mathrm{sb}$ & $0.620 \mathrm{~b}$ & $18.22 \mathrm{ab}$ & $2.280 \mathrm{a}$ \\
\hline 4 & Intercropping and Plectranthusamboinicus extract & $4.27 \mathrm{~d}$ & $0.503 \mathrm{e}$ & $16.76 \mathrm{bc}$ & $1.970 \mathrm{~cd}$ \\
\hline 5 & Basil oil & $5.05 \mathrm{a}$ & $0.710 \mathrm{a}$ & $19.89 \mathrm{a}$ & $2.373 \mathrm{a}$ \\
\hline 6 & Geranium oil & $4.83 \mathrm{abc}$ & $0.560 \mathrm{c}$ & $17.51 \mathrm{abc}$ & $2.097 \mathrm{bc}$ \\
\hline 7 & Camphor oil & $4.86 \mathrm{abc}$ & $0.610 \mathrm{~b}$ & $17.67 \mathrm{abc}$ & $2.107 \mathrm{~b}$ \\
\hline 8 & Garlic oil & $4.69 \mathrm{bc}$ & $0.537 \mathrm{~d}$ & $17.16 \mathrm{abc}$ & $2.030 \mathrm{bcd}$ \\
\hline 9 & Hot pepper extract & $4.58 \mathrm{c}$ & $0.510 \mathrm{e}$ & $16.90 \mathrm{abc}$ & $1.920 \mathrm{~d}$ \\
\hline 10 & Control & $3.44 \mathrm{e}$ & $0.340 \mathrm{~h}$ & $14.65 \mathrm{c}$ & $1.553 \mathrm{e}$ \\
\hline \multirow{2}{*}{\multicolumn{2}{|c|}{ L.S.D $5 \%$}} & 0.28 & 0.02 & 2.1 & 0.82 \\
\hline & & \multicolumn{4}{|c|}{ Second season 2015} \\
\hline 1 & Intercropping with Plectranthusamboinicus & $4.37 \mathrm{~d}$ & $0.457 \mathrm{f}$ & $17.90 \mathrm{c}$ & 2. $423 \mathrm{c}$ \\
\hline 2 & Plectranthusamboinicus extract & $4.80 \mathrm{~cd}$ & $0.483 \mathrm{ef}$ & $20.76 \mathrm{~b}$ & $2.613 \mathrm{bc}$ \\
\hline 3 & Citronella oil & $5.63 \mathrm{ab}$ & $0.643 \mathrm{~b}$ & $23.89 \mathrm{a}$ & $2.867 \mathrm{~b}$ \\
\hline 4 & Intercropping and Plectranthusamboinicus extract & $5.12 \mathrm{bc}$ & $0.540 \mathrm{de}$ & $21.20 \mathrm{~b}$ & $2.647 \mathrm{bc}$ \\
\hline 5 & Basil oil & $6.05 \mathrm{a}$ & $0.737 \mathrm{a}$ & $24.26 \mathrm{a}$ & $3.200 \mathrm{a}$ \\
\hline 6 & Geranium oil & $5.30 \mathrm{bc}$ & $0.577 \mathrm{~cd}$ & $21.92 b$ & $2.780 \mathrm{~b}$ \\
\hline 7 & Camphor oil & $5.32 \mathrm{bc}$ & $0.620 \mathrm{bc}$ & $23.58 \mathrm{a}$ & $2.827 \mathrm{~b}$ \\
\hline 8 & Garlic oil & $5.26 \mathrm{bc}$ & $0.573 \mathrm{~cd}$ & $21.70 \mathrm{~b}$ & $2.727 \mathrm{~b}$ \\
\hline 9 & Hot pepper extract & $5.18 \mathrm{bc}$ & $0.557 \mathrm{~cd}$ & $21.55 \mathrm{~b}$ & $2.707 \mathrm{~b}$ \\
\hline 10 & Control & $4.30 \mathrm{~d}$ & $0.427 \mathrm{f}$ & $16.90 \mathrm{c}$ & $2.410 \mathrm{c}$ \\
\hline L.S & D 5\% & 0.68 & 0.06 & 2.1 & 0.23 \\
\hline
\end{tabular}

\section{Conclusion}

Finally, it could be concluded that foliar spray with some aromatic oils or extracts were important to reduce insects and mite pests infestation on cucumber plants (evaluation for both efficacy against insect and mite pests and plant safety) instead of synthetic pesticides not only to obtained good yield but also without negative effects on environment and human health, while, the new pest alternatives offer acceptable decrease of pest population, preserving human health also afford good yield both qualitatively and quantitively.

\section{References}

Anonymous (1990): Association of official Analytical chemists' (A.O.A.C.) methods of Analysis Washington, D.C. 2004.

Derridj, S.; Gregoire, V.; Boutin, J. P. and Fiala, V. (1989). Plant growth stages in the interspecific oviposition preference of the European corn borer and relation with chemicals present on the leaf surface. Entomologia Experimentalis and Applicata, 53: 267-276.

Dubois, M.; Smith, F.; Gilles, K. A.; Hammilton, J.K. and Robers, P.A. (1956): Colorimetric method for determination of sugars and related substances. Anal. Chem., 28 (3): 350-356.

Farouk, S. and Osman, M. A. (2012). Alleviation of oxidative stress induced by spider mite invasion through application of elicitors in bean plants. Egyptian J. Biol., 14: 1-13.

Gafar, M.O.;Dagash, Y. M.; Mustafa, M. and AlzenO. M. (2010). The Residual effect of Malathion (Organophosphate) and Sevin (Carbamate) application on sugar beet (Chenpodiaceae) Growth, Journal of Science and Technology 11 (2) ISSN 1605 - 427 X (C) Sudan University of Science and Technology

Gomez, K. A. and Gomez A. A. (1984). Statistical procedures for agricultural research. Joho Wiley and sons Inc. New York p68.

Hildebrand, D. F.; Rodriguez, J. G.; Brown, G. C. and Volden, C. S. (1986). Two-spotted spider mite (Acari: Tetranychidae) infestations on soybeans: Effect on composition and growth of susceptible and resistant cultivars. J. Econ. Entomol., 79: 915-921

Kalia (2015) www.amnh.org/.../plant-extracts-asnatural-insecticides

Mangoud, A.A.H. and Halawa A. M. (2007) Effect of different plant extract against two spotted spider mite, Tetranychusurticae Koch and 
predatory mite, phytoseiuluspersimilis A.-H. Egypt. J. Agric. Res., 86(3), 2008

Metwally, A. M.; El-Naggar, M.E.;El-Khateeb, H.M. and Abou-Zaid A.M.M. (2008): Effect of intercropping of some aromatic plants on the infestation levels of Tetranychusurticae Koch to cucumber plants and its resulted yield in both open and greenhouse conditions. Egypt J. Agric. Res, 86(1) pp. 259-268.

Mohamed, E.M. and Mahasen A. Abdl-Aziz (2008): Insecticidal activity of the marigold, tagetesminuta L. extract (asterales: asteraceae) against some sap-sucking insect on cotton plants.Egypt .J. Agric. Res, 86(2): 479-487

Prakash, A.; Tiwari, S.N. and Rao, J. (1990). Exploitation of natural plant products for management of pests and diseases in rice ecosystems. Proc. Symp. Growth, Dev. Resource Conserv. 23-36 PP

Rebek, E.J., and C.S. Sadof. 2003. Effects of pesticide applications on the Euonymus scale (Homoptera: Diaspididae) and its parasitoid, Encarsiacitrina (Hymenoptera: Aphelinidae). J. Economic Entomol., 96(2):446-452

Raymond, A. C.;Cindy, L. G.; Stephen, R. K.; Nanette, A. K. and Kenneth E. K.(2009). Effect of Commercially Available Plant -Derived Essentiial Oil Products on Arthropod Pests J Econ Entomol. 2009 Aug; 102 (4):1567-79.

Senthil, V.;Ramasamy, P.;Elaiyaraja, C. and Elizabeth, A. R. (2010). Some phytochemical properties affected by the infection of leaf spot disease of Cucumissativus (Linnaeus) caused by Penicilliumnotatum. Afr. J. Basic and Appl. Sci., 2: 64-70.
Schoonhoven, L. M.;Jermy, T. and Loon van, J. J. A. (1998). Plants as insect food: not the ideal. In: Insect-Plant Biology. Chapman and Hall, London, United Kingdom. 83-120 pp.

Sharma, A., P. Kaushal, K.C. Sharma and R. Kumar, 2006. Bioefficacy of some plant products against Diamondback moth Plutellaxylostella L. (Lepidoptera: Yponomeutidae ). J. Entomo. Res. Soc., 30: 213217

Sivritepe, N.; Kumral, N. A.; Erturk, U.; Yerlikaya, C. and Kumral, A. (2009). Responses of grapevines to two-spotted spider mite mediated biotic stress. J. Biol. Sci., 9: 311318.

Swains, T. H. and Hillis, W. E. (1959). Phenolic constituent of Prunusdomestica L.-the quantitative analysis of phenolic constituent. J.Sci. Food Agric., 10: 63-69

Tomczyk, A. (2001). Physiological and biochemical responses of plants to spider mite feeding. In : Acarology, Melbourne, Halliday, R. B., Walter, D. E., Proctor, H. C., Norton, R. A. and Collof, M. J. (eds.). CSIRO Publishing, New York. P: 306-313

Xu, Q.; Barrios C.A.;CutrightT., and Newby, B.Z. (2005). Evaluation of toxicity of capsaicin and zosteric acid and their potential application as antifoulants. Environ. Toxicol., 20(5):467-474.

Yanar D, Kadioğlu I, and Gökçe A. (2011). Acaricidal effects of different plant parts extracts on two-spotted spider mite (Tetranychusurticae Koch). Afri. J. Biotechnol., 10(55): 11745-11750. 
استخدام اساليب جليدة للسيطرة على آفات الخيار الحشرية والحيوانية وتأثيرها على الإنتاجية ويعض الصفات البستانية تحت الصوب.

$$
\begin{aligned}
& \text { *محمد فهمي عبداله حجاب- فهيمة هلال أيوب- "*بران عبد الفتاح بدران - "منى ابراهيم عمار }
\end{aligned}
$$

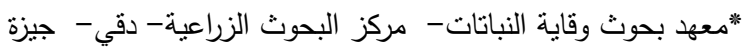

$$
\begin{aligned}
& \text { معهد بحوث البساتين- مركز البحوث الزراعية- دقي - جيزة }
\end{aligned}
$$

تم دراسـة تأثثر النحميل والرش ببعض الزيوت ومستخلصـات بعض النباتـات الطبيـة والعطريـة على بعض الصفات البستانية لنبات الخيار

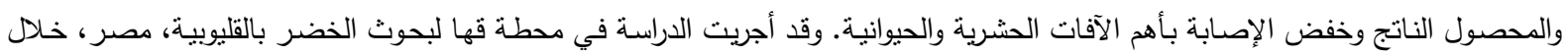

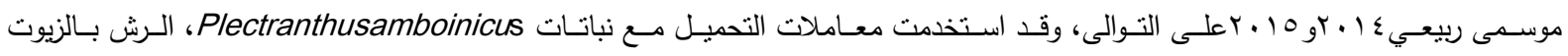

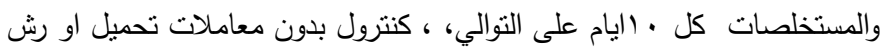

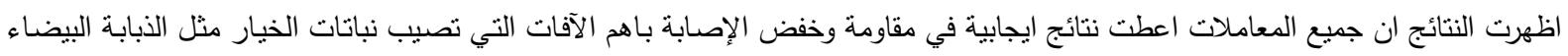

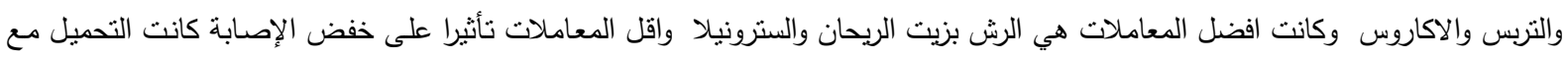
نبات Plectranthusamboinicus والكنترول بدون معاملات.

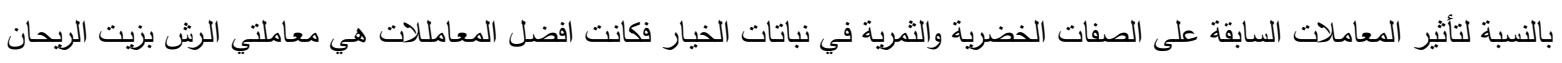

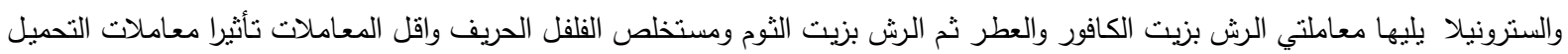
والرش بمستخلص Plectranthusamboinicus و الكنترول 